Conference on Africa, New York, April 1944

A CONFrRznce was held under the auspices of the Council on African Affairs, in order to discuss means for ' securing international agreements and establishing effective international machinery for securing the social, economic, and political advancement of African and other colonial peoples consistent with the Atlantic Charter ... and with requirements for achieving world security and peace' $:$ The conference, which was attended by Negro and white Americans, as well as by representatives of the peoples of Africa and of the British West Indies, discussed such questions as Forced Labour, Self-government, Industrial Development of Africa, and an International Authority for Colonial Development. Addresses were given by Dr. Max Yergan and Paul Robeson.

\title{
Members' Subscriptions to the Institute
}

Copres of Africa have, during the last two years, been sent to all members who have not actually cancelled their membership, even though, in some cases, subscriptions which have lapsed since 1939 have not been renewed. It will not be possible to continue doing this in future. Members are therefore reminded that the annual subscription of $f_{\mathrm{r}}$ is payable in January of each year, and that subscriptions for 1945 are now due. To ensure receipt of Africa in 1945, a remittance should be sent without delay.

I For a Now Africa, proceedings of the Conference on Africa, New York, 14 April 1944. Council on African Affairs Inc. so cents. 